\title{
Anal fissures: Open lateral internal sphincterotomy results
}

\author{
Abdul-Wahid M Salih* \\ Department of Surgery, College of Medicine, University of Sulaimani, Kurdistan Region, Iraq
}

Received: August 18, 2015

Accepted: October 24, $2015 \quad$ Online Published: November 10, 2015

DOI: $10.5430 /$ jer.v2n1p87

URL: http://dx.doi.org/10.5430/jer.v2n1p87

\begin{abstract}
Background: Lateral Internal Sphincterotomy is the procedure of choice for chronic anal fissure because it relieves symptoms and heals the fissure in nearly all patients. However, data on its postoperative complications are limited particularly fecal incontinence. Therefore, the aim of this study is to investigate the results of this procedure in terms of recurrence rate, complications and patient satisfaction.

Methods: The medical records of 80 patients from 4 centers were collected during 20 months and evaluated retrospectively. Results: Incontinence was observed in $2(2.5 \%)$ patients. The patients were discharged at the same day of the operation. During the average follow-up of 24 months, two patients (2.5\%) developed recurrent disease. In addition, patients' satisfaction was high $(95 \%)$.

Conclusions: Lateral internal sphincterotomy is the procedure of choice for chronic anal fissure because it relieves symptoms and heals the fissure in nearly all patients with very low rate of complications, negligible recurrence and good patient satisfaction.
\end{abstract}

Key Words: Lateral internal sphincterotomy, Incontinence, Patient satisfaction, Anal fissure

\section{INTRODUCTION}

Anal fissure is a linear tear in the skin of the distal anal canal below the dentate line. It is a common condition affecting all age groups particularly young adults. Men and women are equally affected. The pain is often severe and may vary from few minutes to several hours. ${ }^{[1]}$ Chronic anal fissures associate with persistent hypertonia and spasm of the internal anal sphincter but its mechanisms is unclear. Bowel movements result in more pain, and more anal spasm leading to decreasing blood flow to the area, and the cycle propagates. Combination of these factors with internal anal sphincter hypertonia explain poor wound healing and pain associated with chronic anal fissures. ${ }^{[1-3]}$ Treatment strategies are aimed at interrupting this cycle to promote healing of the fissures. ${ }^{[5]}$ Classic treatment is to reduce the anal tone and eliminate sphincteric spasm. These findings suggest that the anal spasm may predate the onset of the fissure. The internal sphincter spasm is probably not secondary to pain as the application of topical local anaesthetic to a fissure alleviates the pain but does not reduce the anal spasm. ${ }^{[6]}$ The increase in anal sphincter muscle pressure results in a decrease in blood flow to the site of the injury, thus impairing healing of the wound. It has been reported that in elderly and postpartum patients anal fissures are associated with normal and even hypotonic sphincters..$^{[7,8]}$

Despite the advent of new modalities in the conservative treatment of chronic fissures, they frequently need surgical treatment. Several surgical methods are accepted for the

\footnotetext{
* Correspondence: Abdul-Wahid M Salih, Project Coordinator; Email: Abdulwahid.salih@univsul.edu.iq; Address: Department of surgery, School of Medicine, University of Sulaimani, Iraq.
} 
treatment of chronic anal fissures. The most popular one is anal dilatation while recently lateral sphincterotomyhas is more promising. This is a minor operation, which is usually done as day case surgery. ${ }^{[9,10]}$ Early sphincterotomy with generous division of the internal anal sphincter muscle are recommended. ${ }^{[1]}$ The objective of the current study is to evaluate the results of this procedure in terms of recurrence rate, complications and patient satisfaction.

\section{Patients and methods}

\subsection{Study setting}

This is multicenter based study. Sample collected from 4 hospitals.

\subsection{Study design}

A retrospective cohort design was applied for the implementation of the study.

\subsection{Target population}

A single cohort of 85 patients who underwent surgery between (2012 and 2014) were reviewed retrospectively using structured interview questionnaire which included information on socio-demography of the patients, complications, recurrence of the disease and patients satisfaction. Five patients were excluded from the study because of missed information, the remaining 80 patients underwent complete analysis.

\subsection{Study procedures}

Lateral internal sphincterotomy done with the patient under regional or general anesthesia in the lithotomy position by a standard open technique, which included 5-mm incision starting from right side of the anus into the perianal skin along the intersphinteric groove (see Figure 1). The internal anal sphincter was then dissected and a segment withdrawn with a pair of artery forces and divided with diathermy. The procedure involves division of the internal anal sphincter laterally. ${ }^{[12,13]}$ From its distal most end up to the dentate line, or for a distance equal to that of the fissure. ${ }^{[14]}$ The sphincter was divided in an open (through a radial or circumferential incision) fashion. Wound left open to heal by secondary intention. ${ }^{[15]}$ Sentinel skin tags, fissure edges and bed were removed (fissurectomy), and rarely combined with hemorrhoidectomy. The operation takes less than 20 minutes. The surgery is performed as an outpatient, same-day procedure. ${ }^{[16]}$ The researchers then contacted patients by phone, letter or home visit to request a meeting with the researchers for the purpose of obtaining informed consent. Following consent, sociodemographic data and history of various exposures were collected using a structured interview which is researcher-administered and anthropometric measures were conducted.

\section{Statistical anAlysis}

Data was collected and coded. The collected data were reviewed and analyzed using the Statistical Package for Social sciences (SPSS version 22). Descriptive statistics was used to describe the study sample.

\section{ETHICAL CONSIDERATIONS}

The researchers obtained the approval of the Sulaimani medical school Ethical Committee for conducting this study. It is complied with the international Ethical Research Guidelines. Informed consents were obtained from the participants and confidentiality was assured.

\section{RESUlTS}

\subsection{Main characteristics of participants}

The study included 19 males (23.7\%) and 61 females $(76.3 \%)$ with a mean $\pm S D$ of age of $31.09 \pm 7.77$ years (range, 20 to 62 years). 60 patients $(75.0 \%)$ presented as chronic and 20 patients $(25.0 \%)$ presents as acute anal fissures. The distribution of patients in according to demographic characteristics and return to work and are given in Table 1.

Table 1. Main demographic characteristics of the participants

\begin{tabular}{ll}
\hline Characteristics & No. (\%) \\
\hline Gender & $19(23.7)$ \\
Male & $61(76.3)$ \\
Female & \\
Address & $49(61.2)$ \\
Inside city & $31(38.8)$ \\
Outside city & \\
Married & $66(82.5)$ \\
Yes & $14(17.5)$ \\
No & \\
Presentation of the disease & \\
Constipation & $65(81.25)$ \\
Yes & $15(18.75)$ \\
No & \\
Bleeding & $56(70.0)$ \\
Yes & $24(30.0)$ \\
No & \\
Pain & $62(77.5)$ \\
Yes & $18(22.5)$ \\
No & 20 \\
Median Duration of the disease/months & \\
\hline
\end{tabular}

ISSN 2377-9306 E-ISSN 2377-9330 


\subsection{Post-operative complications}

The distribution of complications is shown in Table 2, which were recorded during 24 months of follow-up. The patients were discharged at the same day of the operation.

Table 2. Distribution of anal fissure patients according post-operative complications, Recurrence and patient's satisfaction

\begin{tabular}{ll}
\hline Complications & No. (\%) \\
\hline Constipation & $17(38.6)$ \\
Yes & $27(61.4)$ \\
No & \\
Pain & $14(17.5)$ \\
Yes & $35(82.5)$ \\
No & \\
Bleeding & $12(15.4)$ \\
Yes & $68(84.6)$ \\
No & \\
Recurrence & $2(2.5)$ \\
Yes & $78(97.5)$ \\
No & \\
Patients satisfaction & $77(96.25)$ \\
Yes & $3(3.75)$ \\
No
\end{tabular}
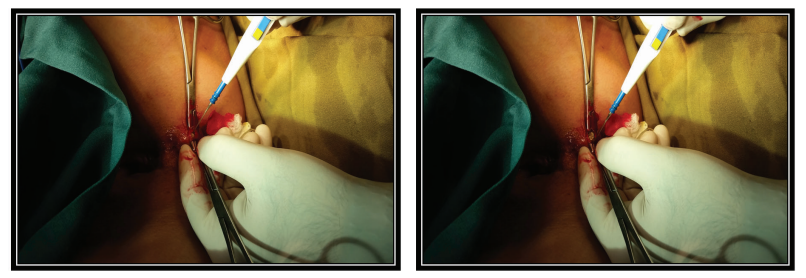

Figure 1. Open lateral internal sphincterotomy

\section{Discussion}

Treatment of anal fissures by sphincterotomy was first suggested in 1818 by Boyer. ${ }^{[17]}$ Over the last century, a wide variety of surgical methods (anal dilation, fissurectomy, advanced flap, posterior and lateral sphincterotomy) have been described for management of chronic anal fissure. Since its introduction by Eisenhammer in 1951, lateral internal sphincterotomy has been used with increasing frequency and it is now considered the treatment of choice for chronic anal fissures. ${ }^{[19-25]}$

The administration of pharmacological preparations that relaxes the internal anal sphincter effectively reducing anal pressure, can lead to healing of chronic fissures. However, this effect on the muscle is reversible and resting pressures appear to return to original values once treatment is discontinued, even after the fissure has healed. ${ }^{[13]}$

Various medical treatment has been tried for management Published by Sciedu Press of chronic anal fissures but none of them approached the efficacy of surgical sphincterectomy, although all patients were free from incontinence. ${ }^{[27]}$ In a prospective randomised controlled study carried out by Valizedah et al. ${ }^{[28]}$ botulinum toxin injection and lateral internal sphincterotomy were compared in the treatment of chronic anal fissure. After a follow up period of six months, it was found that the rate of recurrence was significantly higher in botulinum toxin injection Group. ${ }^{[29]}$ Richard et al. ${ }^{[14]}$ concluded that surgical sphincterotomy improved healing rate at 6 weeks ( $89 \%$ vs. 29\%) and reduced the further requirement for surgery (3\% vs. 89\%) in his trial of 82 patients $^{[30]}$.

Precise and controlled division of the internal anal sphincter muscle is a highly effective and commonly used method to treat chronic and refractory anal fissures, with success rates reported to be over $90 \%$ and has a better success rate than any medicine that is used to treat long-term anal fissures but it is associated with potential long-term complications. ${ }^{\text {[31-34] }}$ Recurrence rates after sphincterotomy are exceedingly low when properly performed by a surgeon. We are utilizing the fissurectomy wound to enhance healing acceleration. Our study is in line with other studies in term of short hospital stay, rapid wound healing, low recurrence rate, and very low risk of incontinence. ${ }^{[35]}$ Surgery is highly successful and our results only go to support it.

High rate of chronic anal fissures among female patients in our study $(76.3 \%)$ can be explained by social and cultural factors. As far as there is no female anologist in our region, female patients feel shame to consult male surgeon until their condition progress to chronic fissure which then need surgical interventions. However more studies with bigger sample size are necessary to confirm this finding and expose underline causes.

A number of limitations could be considered for this study. First: small sample size. Second: the quality of the recorded data was another matter. Some information was missed regarding the patients for instance contact number, therefore we excluded those patients in this study. Finally, this study was retrospective and the it was not recruited and compared with other surgical procedure.

\section{Conclusions}

Lateral internal sphincterotomy is the procedure of choice for chronic anal fissure because it relieves symptoms and heals the fissure in nearly all patients. The Advantages are good symptomatic relief, high rate of healing, and good patient satisfaction. It has very few complications and negligible rate of recurrence and incontinence. Future studies should be planned with a larger series of patients, including the comparison with other modalities of treatment. 


\section{REFERENCES}

[1] Jonas M, Scholefield JH, Holzheimer RG, et al. Surgical Treatment: Evidence-Based and Problem-Oriented. Munich: Zuckschwerdt. 2001. Available from: http://www.ncbi.nlm.nih.gov/b ooks/NBK6878/

[2] Gibbons CP, Read NW. Anal Hypertonia in fissures: cause or effect? Br J Surg. 1986; 73: 443-5. PMid:3719268 http://dx.doi.org /10.1002/bjs. 1800730609

[3] Abcarian H, Lakshmanan S, Read DR, et al. The role of internal sphincter in chronic anal fissures. Dis ColonRectum. 1982; 25(6): 525-8. http://dx.doi .org/10.1007/BF02564159

[4] Lund JN, Scholefield JH. Etiology and treatment of anal fissure. Br J Surg. 1996; 83: 1335-44. http://dx.doi.org/10.1002/bjs.1 800831006

[5] Anal Fissure Expanded Information. Michael A. Valente, DO, on behalf of the ASCRS Public Relations Committee (C) 2012 American Society of Colon \& Rectal Surgeons.

[6] Jonas M, Scholefield JH. Surgical Treatment: Evidence-Based and Problem-Oriented. Department of Surgery, University Hospital, Nottingham, UK.

[7] Corby H, Donnelly VS, O'Herlihy C, et al. Anal canal pressures are low in women with postpartum anal fissure. Br J Surg. 1997; 84: 86-88. PMid:9043464 http://dx.doi.org/10.1002/bjs.1 800840132

[8] Bove A, Balzano A, Perrotti P, et al. Different anal pressure profiles in patients with anal fissure. Tech Coloproctol. 2004; 8: 151-156. PMid:15654521 http://dx.doi.org/10.1007/s10151-004-0 079-z

[9] Concepts in pathogenesis and treatment of chronic anal fissure-a review of the literature Department of General, Vascular, and Thoracic Surgery, Benjamin Franklin Medical Center, Freie Universität Berlin, Berlin, Germany Received 9 September 2002, Accepted 2 December 2002, Available online 10 June 2003.

[10] http://www.patient.co.uk/health/anal-fissure. last access 7 Janauary at $11 \mathrm{pm}$.

[11] Lockhart-Mummery HE. Fissure-in-ano. In: Rob C, Smith R, editors. Operative Surgery. London: Butterworth. 1957: 11-3.

[12] Notaras MJ. Lateral subcutaneous sphincterotomy for anal fissure: a new technique. Proc R Soc Med. 1969; 62: 713-715. PMid:5803521

[13] Eisenhammer S. The surgical correction of chronic anal (sphincteric) contracture. S Afr Med J. 1951; 25: 486-489. PMid:14866486

[14] Littlejohn DR, Newstead GL. Tailored lateral sphincterotomy for anal fissure. Dis Colon Rectum. 1997; 40(12): 1439-1442. http: //dx.doi.org/10.1007/BF02070709

[15] Aysen E, Aren A, Ayar E. Lateral internal sphincterotomy incision: suture or not? A prospective randomized controlled trial. Am Surg. 2004: 187: 291-294. PMid:14769323 http://dx.doi .org/10.10 16/j . amj surg. 2003.11.011

[16] Anal Fissure Expanded Information author: Michael A. Valente, DO, on behalf of the ASCRS Public Relations Committee (c) 2012 American Society of Colon \& Rectal Surgeons.

[17] McNamara MJ, Percy JP, Fielding IR. A manometric study of anal fissure treated by subcutaneous lateral internal sphincterotomy. Ann Surg. 1990; 211: 235-238.

[18] Eisenhammer S. The evaluation of the internal anal sphincterotomy operation with special reference to anal fissure. Surg Gynecol Obstet. 1959; 109: 583-590.

[19] Nelson RL. Meta-analysis of operative techniques for fissure-inano. Dis Colon Rectum. 1999; 42: 1424-1428. PMid:10566530 http: //dx.doi.org/10.1007/BF02235041
[20] Garcia-Aguilar J, Belmonte C, Wong WD, et al. Open vs. closed sphincterotomy for chronic anal fissure: long-term results. Dis Colon Rectum. 1996; 39: 440-443. PMid:8878506 http://dx.doi .org /10.1007/BF02054061

[21] Argov S, Levandovsky O. Open lateral sphincterotomy is still the best treatment for chronic anal fissure. Am J Surg. 2000; 179: 201-202. http://dx.doi.org/10.1016/S0002-9610(00)00307-X

[22] Gordon PH, Vasilevsky CA. Symposium on outpatient anorectal procedures. Lateral internal sphincterotomy: rationale, technique and anesthesia. Can Surg. 1985; 28: 228-230.

[23] Hiltunen KM, Matikainen M. Closed lateral subcutaneous sphincterotomy under local anaesthesia in the treatment of chronic anal fissure. Ann Chir Gynaecol. 1991; 80: 353-356. PMid:1814259

[24] Jorge JMN, Wexner SD. Etiology and management of fecal incontinence. Dis Colon Rectum. 1993; 36: 77-97. http://dx.doi.org /10.1007/BF02050307

[25] Mc Callion K, Gardiner KR. Progress in the understanding and treatment of chronic anal fissure. Postgrad Med. J. 2001; 77: 753-758. http://dx.doi.org/10.1136/pmj.77.914.753

[26] Sinha R, Kaiser AM. Efficacy of management algorithm for reducing need for Sphincterotomy in chronic anal fissures. Colorectal Dis. 2012; 14: 760-764. PMid:21801296 http://dx.doi.org/10.11 $11 / j .1463-1318.2011 .02736 . x$

[27] Nelson RL, Thomas K, Morgan J, et al. Non surgical therapy for anal fissure. Cochrane Database of Systematic Reviews. 2012; (15) 2: CD003431. http://dx.doi.org/10.1002/14651858.CD00 3431.pub3

[28] Valizedah N, Jalaly NY, Hassanzadeh M, et al. Botulinum toxin injection versus lateral internal sphincterotomy for the treatment of chronic anal fissure: randomized prospective controlled trial. Langenbecks Arch Surg. 2012. PMid:22430300 http://dx. doi .org /10.1007/s00423-012-0948-2

[29] Arroyo A, Pérez F, Serrano P, et al. Surgical vs chemical (Botulinum Toxin) sphincterotomy for chronic anal fissure. Long-term results of a prospective randomized clinical and manometric study. Am J Surg. 2005; 189: 429-434. PMid:15820455 http://dx.doi.org/10.10 $16 / j$.amj surg. 2004.06.045

[30] Richard CS, Gregoire R, Plewes EA, et al. Internal sphincterotomyis superior to topical nitroglycerin in the treatment of chronic anal fissure: results of a randomized, controlled trialby the Canadian Colorectal Surgical Trials Group. Dis ColonRectum. 2000; 43: 1048-1057.

[31] Lindsey I, Cunningham C, Jones OM, et al. Fissurectomy-botulinum toxin: a novel sphincter-sparing procedure for medically resistant chronic anal fissure. Dis Colon Rectum. 2004; 47(11): 1947-52. PMid:15622590 http://dx.doi.org/10.1007/s10350-004-0 693-x

[32] Engel AF, Eijsbouts QA, Balk AG. Fissurectomy and isosorbide dinitrate for chronic fissure in ano not responding to conservative treatment, Br J Surg. 2002; 89(1): 78-83. PMid:11851668 http://dx.doi.org/10.1046/j.0007-1323.2001.01958.x

[33] Meier Z, Eissen J. Chronic anal fissure therapy. Kongressbd. Dtsch Ges Chir Kongr. 2001; 118: 654-6.

[34] Richard CS, Gregoire R, Plewes EA, et al. Internal sphincterotomy is superior to topical nitroglycerin in the treatment of chronic anal fissure: Results of a randomized controlled trial by the Canadian Colorectal Surgical Trials Group. Dis Colon Rectum. 2000; 43: 1048-58. PMid:10950002 http://dx.doi.org/10.1007/BF02236548

[35] Abcarian H. Surgical correction of chronic anal fissure: results of lateral internal sphincterotomy $v s$. fissurectomy-midline Sphincterotomy. Dis Colon Rectum. 1980; 23(1): 31-6. PMid:7379649 http://dx.doi.org/10.1007/BF02587197 